UDC $579.22+577.15$

\title{
Structural and functional peculiarities of aspartic proteases of basidiomycetes
}

\author{
V. V. Sakovich \\ Polessky State University \\ 23, Dneprovskoy flotilii, Pinsk, Republic of Belarus, 225710 \\ mrs.valeryia@mail.ru
}

\begin{abstract}
The vast diversity of fungal proteases and the specificity of their action have attracted attention in attempts to exploit their physiological and biotechnological applications. These enzymes are widely used in biotechnology, mainly in food, leather, and detergent industries, in ecological bioremediation processes and to produce therapeutic peptides. This review covers various aspects of aspartic proteases from basidiomycetes including sources, production, structural peculiarities, physicochemical properties and their diverse applications.
\end{abstract}

Keyword s: Proteolytic enzymes, physical and chemical properties

\section{Introduction}

Basidiomycetes are used in many industrial processes for the production of enzymes and metabolites. Low material costs along with high productivity are among numerous advantages offered by the enzymes production by fungi. Fungal enzymes are easily recoverable from the media. Besides, protease production of fungal origin has an advantage over bacterial proteases as the use of fungi as an enzyme producer is safer than the use of bacteria. Fungi are normally recognized as GRAS (generally regarded as safe) [1].

The proteolytic enzymes are subdivided into two major groups, exopeptidases and endopeptidases. The MEROPS system groups the en- zymes according to their tertiary structure, considering the order of catalytic residues or the motif sequences around these residues. According to this system the peptidases are clustered into the clans comprising families. The clans are identified by two letters. The first letter relates to the catalytic mechanism as follows: A (aspartic), C (cysteine), M (metallo), S (serine), T (threonine), G (glutamic) or $\mathrm{U}$ (unknown mechanism). The second letter is added sequentially [2].

Fungal proteases are grouped into 4 main classes. In turn, the endopeptidases are divided into four subgroups based on their catalytic mechanism, serine proteases (E.C. 2.4.21),

(C) 2020 V. V. Sakovich; Published by the Institute of Molecular Biology and Genetics, NAS of Ukraine on behalf of Biopolymers and Cell. This is an Open Access article distributed under the terms of the Creative Commons Attribution License (http://creativecommons.org/licenses/by/4.0/), which permits unrestricted reuse, distribution, and reproduction in any medium, provided the original work is properly cited 
cysteine proteases (E.C. 2.4.22), aspartic proteases (E.C.2.4.23) and metalloproteases (E.C. 2.4.24). The characteristic of these classes is given below (see Table 1).

Serine proteinases (EC 3.4.21) have a triad of amino acid residues in the active center, which includes serine, aspartic acid and histidine. The subgroup of serine proteinases includes extracellular proteases from Phanerochaetechrysosporium, Sporotrichumpulverulentum, Irpexlacteus, Pleurotusostreatus, Serpulalacrymans and Schizophyllum commune. Serine proteinases predominate in the proteolytic complex of Laetiporussulphureus and Leccinumscabrum $[5,6]$.

Cysteine (EC 3.4.22) proteinases contain cysteine and histidine residues in the active site. Some proteases from $P$. ostreatus belong to this group [7]. The question of the secretion of cysteine proteinases by fungi remains open. An analysis of a significant number of publications suggests that at least micromycetes in the vast majority of cases secrete only the following proteases: serine, aspartate and metalloproteinases [8].

Metalloproteinases (EC 3.4.24) require metal ions $\left(\mathrm{Mg}^{2+}, \mathrm{Mn}^{2+}, \mathrm{Co}^{2+}, \mathrm{Zn}^{2+}\right)$ to ex- hibit enzymatic activity and are suppressed by the substances that bind these metals: ethylenediaminetetraacetic acid (EDTA), o-phenanthroline, etc. Metalloproteases were isolated and secreted by Hypsizygus and Flammulina $[9,10]$. Metalloproteinases were found in the vegetative mycelium of Chondrostereumpurpureum and Hypsizygusmarmoreus, as well as in the fruit bodies of $P$. ostreatus [11-14].

Aspartate (EC 3.4.23) proteinases contain two carboxylic acid groups in the catalytic center. These proteinases were isolated from the mycelium of Phanerochaetechrysosporium, Amanita muscaria and Irpexlacteus [15-18].

Aspartate proteinases belong to the group of proteolytic enzymes that are active in acidic environment. All milk-clotting enzymes used in industry are aspartic proteinases [18, 19]. These enzymes are used in the cheese production as milk-clotting enzymes (substitutes for rennet). They are found in animal tissues (pepsin, cathepsin, chymosin, renin), plants (aspartate proteinases of lotus seeds, buckwheat, wheat), in microorganisms (penicillopepsin, endotiapepsin) and retroviruses (human immunodeficiency virus proteinases).

Table 1. Classification of proteinases $[3,4]$

\begin{tabular}{l|l|l|l|l|l}
\hline \multicolumn{1}{c|}{ Family } & \multicolumn{1}{c|}{ Cofactors } & \multicolumn{1}{c|}{$\begin{array}{c}\text { Characteristic } \\
\text { active site }\end{array}$} & $\begin{array}{c}\text { Optimal } \\
\text { pH range }\end{array}$ & \multicolumn{1}{|c}{ Inhibitors } & \multicolumn{1}{c}{ Industrial application } \\
\hline Serine proteases & $\mathrm{Ca}^{2+}$ & Asp, Ser, His & $7-11$ & $\begin{array}{l}\text { PMSF, EDTA, phenol, } \\
\text { triamino acetic acid }\end{array}$ & $\begin{array}{l}\text { Detergent, medical and } \\
\text { pharmaceutical }\end{array}$ \\
\hline Metallo proteases & $\mathrm{Zn}^{2+} \mathrm{Ca}^{2+}$ & Glu, Try & $7-9$ & $\begin{array}{l}\text { Chelating agent such as } \\
\text { EDTA, EGTA }\end{array}$ & $\begin{array}{l}\text { Food, medical and } \\
\text { pharmaceutical }\end{array}$ \\
\hline Cysteine proteases & N.d. & Cys, His, Asp & $2-3$ & Indoacetamide, p-CMB & $\begin{array}{l}\text { Food, medical and } \\
\text { pharmaceutical }\end{array}$ \\
\hline Aspartic proteases & $\mathrm{Ca}^{2+}$ & Asp, Asp & $2,5-7$ & Pepstatin, EPNP, DAN & Food and beverage \\
\hline
\end{tabular}

DAN (diazoacetyl-DL-norleucinemethylester, DON 5-diazo-4-oxonorvaline, PMSFphenylmethylsulfonylfluoride, PCMBpchloromercuribenzoicacid, EDTAethylenediaminetetraaceticacid, EGTAethyleneglycoltetraaceticacid, EPNP 1,2-epoxy-3-epoxy 3 ) propane), N.d.notdetermined 
Aspartic proteinases have a tertiary structure consisting of symmetrical lobes forming a catalytic site, each lobe containing an aspartic acid residue, Figure 1.

The molecular weight of aspartic proteinases ranges between 35 and $50 \mathrm{kDA}$, usually consisting of 320-340 amino acid residues. The isoelectric point of these enzymes ranges from 3 to 4.5 .

There are numerous data concerning the effect of divalent ions on the activity of proteinases of fungal origin. It was shown that the activity of extracellular PoS1 protease of the oyster mushroom $P$. ostreatus increased in the presence of both $\mathrm{CaCl}_{2}$ and $\mathrm{Mn}^{2+}$ ions [17].

The effect of $\mathrm{CaCl}_{2}$ on the aggregation of para-casein micelles is explained by its influ- ence on the average coagulation rate. It is hypothesized that electrostatic repulsions and ionic bonds play an important role in the interaction between chymosin and para-casein [18].

\section{Structural features of aspartic protein-} ases. The special structure of aspartic proteinases determines their effect over a wide $\mathrm{pH}$ range. The residues of several aspartic acids of the molecule are located in the inner part and are surrounded by proton donors, sharply lowering their $\mathrm{pK}$. All positively charged groups of molecules, and there are only 5, are neutralized due to their special mutual arrangement regarding the carboxyl groups. Figure 2 shows an example of such an arrangement when the guanidine group of the Arg 315 res-

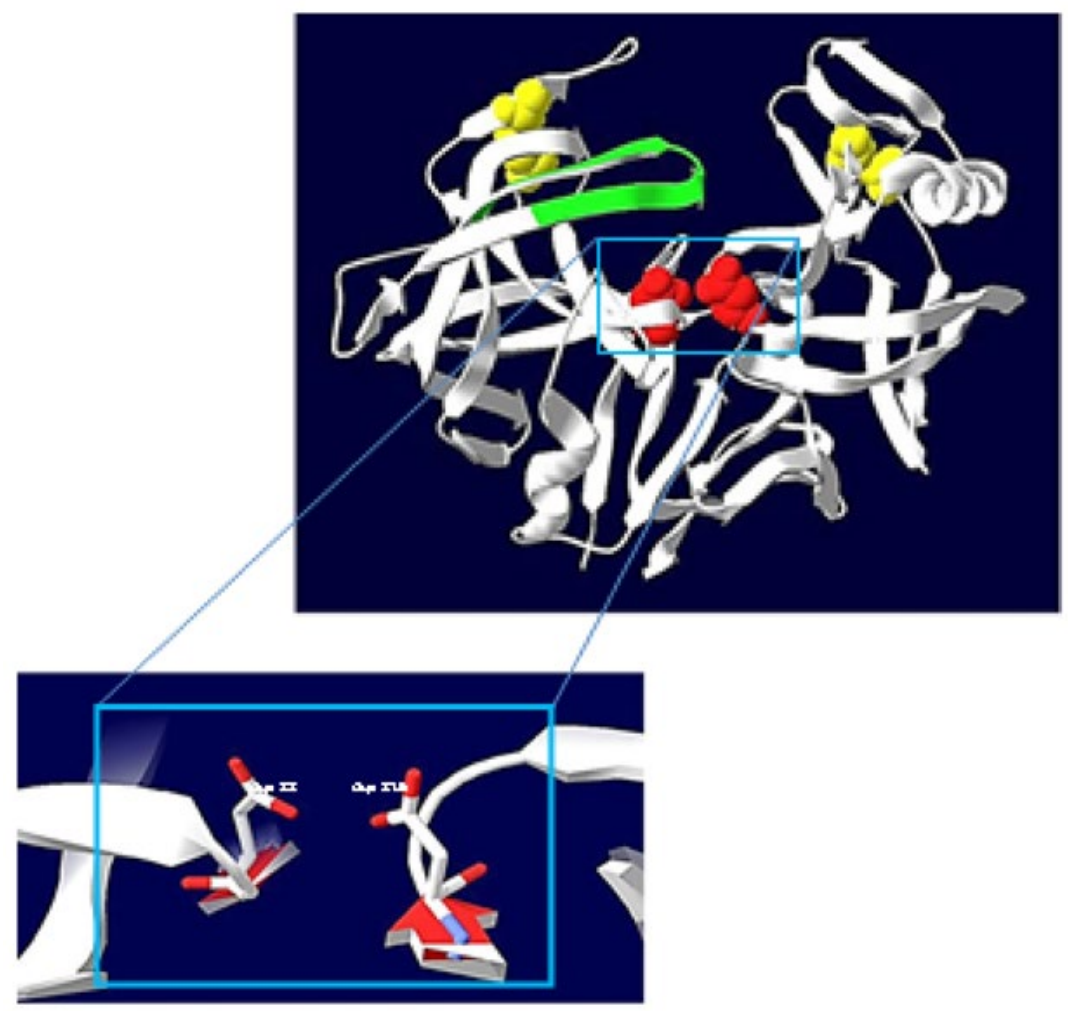

Fig. 1. The three-dimensional structure of the aspartic protease from Candida tropicalis, visualized using Swiss-PDbViewer (v4. 0. 4). The active center is marked in red, disulfide bonds in yellow. The active center is taken out in close-up [20]. 


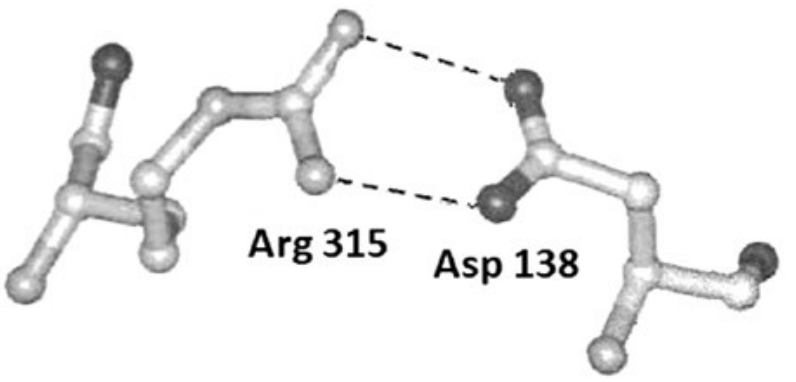

Fig. 2. Relative arrangement of charged amino acid residues in the pepsin molecule - Arg 315 and Asp 138 ion pairs [21].

idue and the carboxyl group Asp 138 are located end-to-end, forming a closed system due to the hydrogen bonds. Such a system is neutral in a wide $\mathrm{pH}$ range. The total charge of the molecule at low $\mathrm{pH}$ is very small, but negative. The negatively charged groups are located far from each other and their interaction cannot lead to destabilization of the molecular structure. Thus, the stability of the molecule and its negative charge at low $\mathrm{pH}$ is due to the mutual arrangement of its carboxyl groups and main residues (see Figure 2) [21].

The mechanism of action of aspartic proteinases. Aspartic proteinases hydrolyze the peptide bond, the mechanism of which has been sufficiently studied [22].
The peptide bond hydrolysis mechanism common to the aspartase representatives suggests a nucleophilic attack by a carbon atom in a carbonyl residue of a substrate protein. The first stage involves the transfer of a proton from water to an aspartic pair, which is then competitively transferred to the oxygen atom in the carbonyl group at the site of cleavage of the peptide bond. Thus, water is an attacking nucleophile, alike in most mechanisms of acid and alkaline hydrolysis. Protonation leads to the formation of a tetrahedral intermediate, the destruction of which is initiated by the transfer of a proton to the aspartate pair and then to the nitrogen atom of the substrate (see Figure 3) [23].

Aspartic proteases from different organisms have their own structural peculiarities. In retroviral proteinases, the catalytic reaction is preceded by the appearance of a charge on one of the carboxyl groups with the other remaining neutral, which occurs due to the interaction of the enzyme with the substrate. The polarization of the Thr-Gly peptide groups, which are hydrogen-bonded to active carbox$y l$, has a significant effect on their properties (figure). This polarization is due to the contacts with water molecules forming continuous chains of hydrogen bonds that are closed on

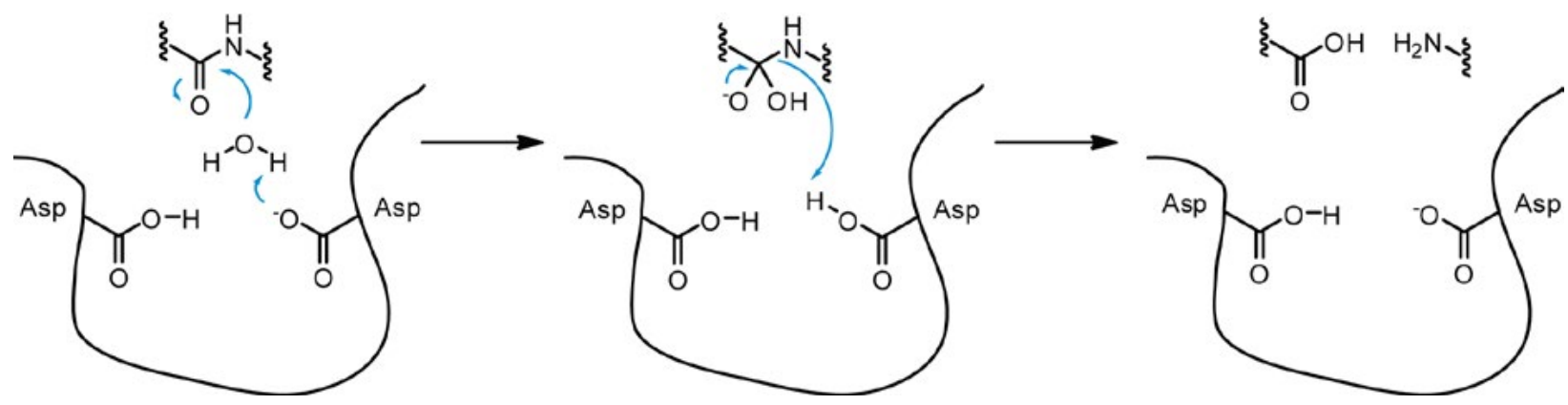

Fig. 3. The mechanism of action of aspartate proteinases 
the groups in contact with the substrate. When the substrate is bound, the symmetry of the chains is broken, which leads to unequal interaction of the peptide groups with the internal oxygen of the active carboxyl. This facilitates the transition of a proton localized between them to one of the carboxyls.

In the proteinases of higher organisms, the charged state of one of the carboxyls and the neutral state of the other exist initially before substrate binding due to the special nature of the interaction of the external oxygen of these carboxyls with the amino acid residues surrounding the catalytic center. The hydrogen bond of Thr 218 with the external oxygen of the Asp 215 carboxyl and the water molecule W1 protects this carboxyl from protonation in an acidic medium (see Figure 4). The carboxyl residue of Asp 32 does not have such protection and remains protonated. Higher organisms are characterized by the presence of a conservative system of interacting groups that are locked on the active carboxyls Thr 218 - Asp 215 - Trp 39 - Tyr 75 - W2 - Ser 35 - Asp 32 , which promotes the development of a catalytic reaction. There are no such interactions in retroviral proteinases. This is an important difference between the structure and, accordingly, the properties of aspartate proteinases of retroviruses and higher organisms [22-25].

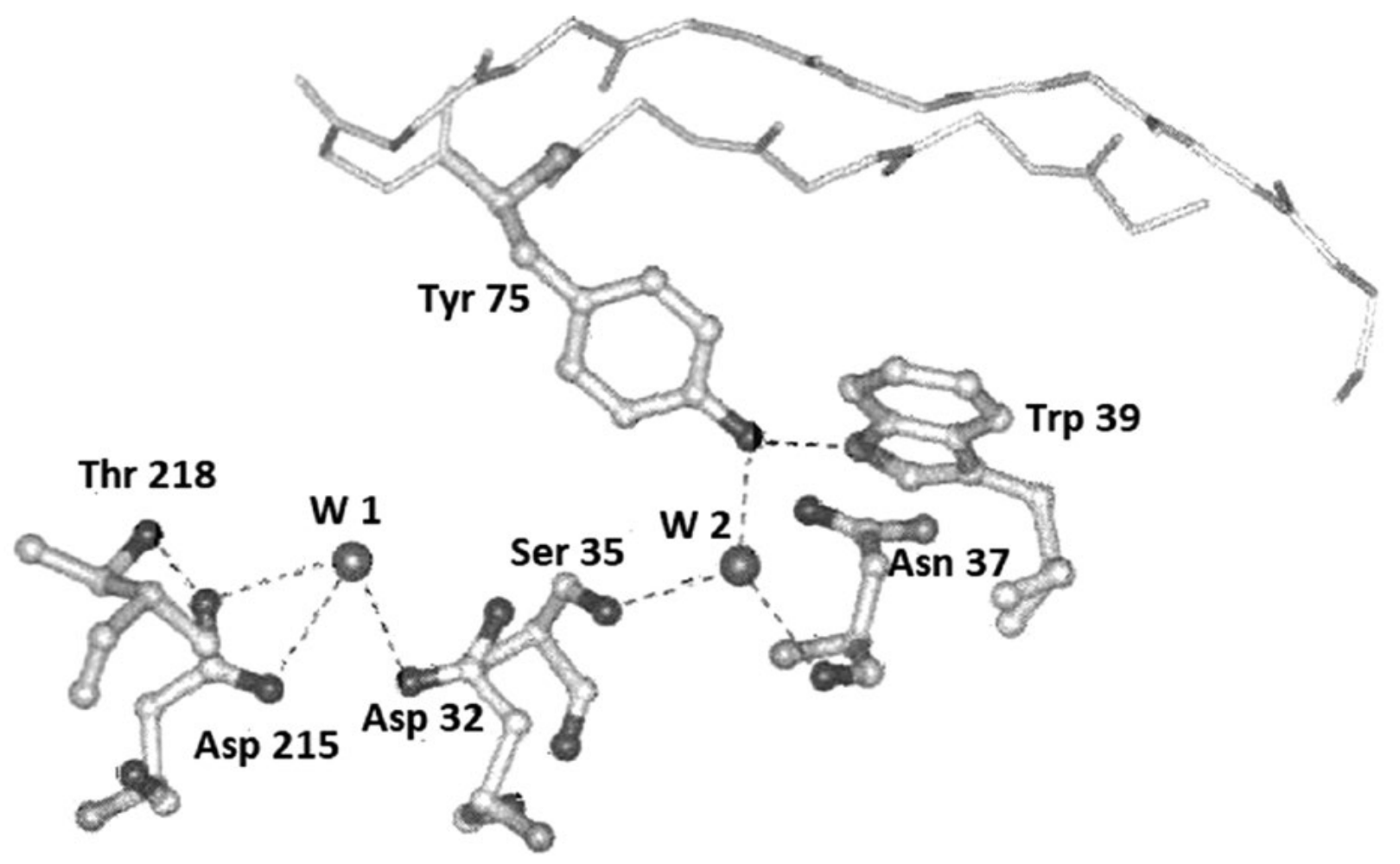

Fig. 4. interaction system of active carboxyl groups in aspartate proteinases of higher organisms (W1, W2 - water molecules) 


\section{Aspartic Proteinases from Basidiomycetes}

In the group of aspartic proteases of fungal origin, the group of basidiomycete proteases occupies a special place. Depending on the origin, there is a variety of enzymes that are used in the production of cheeses and similar foodstuffs: animal rennins (EC 3.4..23.4), plant proteases, microbial milk coagulants and genetically engineered coagulants, most often chymosin.

Fungi produce a wide range of enzymes. The $\mathrm{pH}$ of fungal proteases ranges from 2 to 10 , which demonstrates their wide substrate specificity. However, they have a lower thermal tolerance than bacterial enzymes. Fungal enzymes can be conveniently obtained during solid-phase fermentation [8].

A number of researchers have proposed to use fungi as natural sources of coagulating enzymes, for example, Amylomycesrouxii, Aspergillusniger, Aspergillus Oryzae, Aspergillus Versicolor, Endothia (Cryphonectria) parasitica, Metschnikowiareukaufii, Mucorbaciliformis, NochicomicopsPeniciPeniciopsiPeniciopsi, PenicumiPenicumifici, Penicilli, Rhizopus microspores, RhizopuspusillusvarLindt, Pleurotusostreatus, etc. [26$28]$. Due to the global deficiency of calf chymosin, fungal aspartic proteases have been used as milk clotting enzymes in the dairy industry for about 30 years. The Aspartic protease enzymes obtained from Mucormihei, Mucorpusillus and Cryphonectria (Endothia) parasitica and sold under the trademarks Rennilase ${ }^{\circledR}, \quad$ Fromase ${ }^{\circledR}, \quad$ Novoren $\AA$, Marzyme $\AA$, Hannilase ${ }^{\circledR}$, Marzyme ${ }^{\circledR}$ and

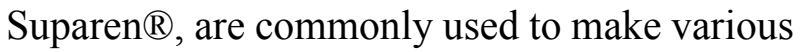
types of cheese [29, 30]. An advantage of the production of such proteinases is that the fungi producing the milk coagulation enzyme are cultivated on nutrient media of various compositions, which makes their production affordable [31].

An addition of basidiomycete protease to milk breaks down the casein micelle-stabilizing protein called kappa casein at the bond Phe105-Met106 and destroys its ability to stabilize the casein micelle. Consequently, pure kappa casein is formed, the aggregates of which in the presence of calcium ions form the cheese curd. The quality of the obtained curd depends on $\mathrm{pH}$ and the ratio of the MCA (milkclotting activity) to proteolytic activity, which should be high. This recommendation is based on the data proving that at a high proteolytic activity of the enzyme preparation, not only the formation of a clot is observed, but also its further hydrolysis. This leads to the appearance of bitter peptides and makes such an enzyme preparation unsuitable for use in cheese making. There are other fungal (e.g. Endothia parasitica) proteases producing milk-clotting enzymes, but they split another peptide bond Ser104-Phe105.

Most of the proteinases of basidiomycetes were obtained in pure form and characterized precisely to have high milk-clotting activity. However, the enzymes should not only be close to chymosin by the substrate specificity, but also be active at low $\mathrm{pH}$ and resistant to heat [32]. Such proteinases were found in $G$. lucidum, lacteus, [ Laetiporus Sulphureus], L. edodes, Pycnoporus Sanguineus, Peurotus Citrinopileatus, Squamosus [33, 34]. So chymosin is stable at $\mathrm{pH}$ 5.3-6.3; the rate of coagulant formation is maximum in the temperature range of $20-42{ }^{\circ} \mathrm{C}$; however, at tem- 
peratures close to the upper boundary, the process speed decreases, so the optimal value lies in the range of $30-40{ }^{\circ} \mathrm{C}$ [35]. It was shown that the temperature stability of aspartases depends on $\mathrm{pH}$, and the presence of other proteins additionally stabilizes the enzyme. The second stage of protein coagulation can be considered as the actual aggregation of protein micelles induced by $\mathrm{Ca}^{2+}$ ions, ending in the formation of a clot. The completeness of coagulation at this stage depends on the concentration of protein, $\mathrm{Ca}^{2+}$ ions, temperature and $\mathrm{pH}[14]$.

Noteworthy, proteinases from Pleurotus Ostreatus are free from the deficiencies (low ration of MCA to PA and thermal stability) that are characteristic for other representatives of basidiomycetes. In turn Pleurotus Ostreatus proteinases have their own characteristics depending on the source of isolation (fruiting bodies, mycelium, culture fluid).

Pleurotus Ostreatus proteases have high MCA and have been obtained as purified preparations. However, based on these enzymes the recombinant analogues have been produced in order to provide better yields and new specialties [36].

Aspartate proteinases from Pleurotus Ostreatus. In the literature of recent years, there are numerous data concerning purified enzyme preparations from oyster mushroom. There are differences in their physicochemical properties, which is possibly due to the method of isolation and purification of enzymes. So the properties of the enzymes obtained from fruiting bodies differ from those of the enzymes of the culture fluid and culture mycelium.

pH The milk-clotting activity of the enzyme preparation from the culture fluid from
Pleurotus Ostreatus was observed in the $\mathrm{pH}$ range from 3.6 to 5.6. The $\mathrm{pH}$ optimum of the enzyme preparation with MCA is represented by two peaks at $\mathrm{pH} 3.6$ and $\mathrm{pH} 5.0$. However, for the practical use of a preparation with MCA, the authors recommend using $\mathrm{pH}$ 3.6, since at this $\mathrm{pH}$, the ratio of ISA / PA is 74: 1 . At $\mathrm{pH}$ 5, the ratio of MCA / PA is only 13: 1 .

So, for proteinases obtained from P.ostreatus fruiting bodies, the $\mathrm{pH}$ at which proteolytic activity is maintained stable, ranges from 4 to 9 [37]. The stability of milk-clotting proteinases from P.ostreatus mycelium is in the $\mathrm{pH}$ range from 3.5 to 7.5 [39]. These results are in accordance with the data obtained for the effect of $\mathrm{pH}$ on the activity of proteinases from P.ostreatus culture fluid [41].

Temperature. The activity of the enzyme preparation from P.ostreatus culture fluid was observed in the temperature range from 25 to $60^{\circ} \mathrm{C}$. In this case, the temperature optimum of proteolytic activity is at $45^{\circ} \mathrm{C}[41,42]$.

The data obtained are consistent with the results of studies of the enzyme preparations from the fruit bodies of P.ostreatus [38].

In contrast, when studying the thermal stability of proteinases from the extract of P.ostreatusfruit bodies, it was found that the activity is maintained up to $55^{\circ} \mathrm{C}$. A further increase in temperature sharply inactivates the milk-clotting enzymes [40].

Substrate specificity. When studying the substrate specificity of the enzyme preparation from the culture fluid, it was found that the aspartic enzyme has a high specificity for the chromogenic substrate Leu-pNa. Chymosin (rennet) specifically cleaves the peptide bond of Phe 105 and Met 106 in the casein molecule. A high degree of hydrolysis of the Leu- 
pNa substrate can be explained by the fact that both amino acids (Leu and Phe) according to the modern classification belong to the same group (amino acids containing non-polar hydrophobic R-groups). The authors recommend Leu-pNa for the work with the enzyme preparation from the culture fluid [42].

When studying the properties of the enzyme preparation from $P$. ostreatus mycelium, the highest degree of hydrolysis was shown for substrate S-2586 [37].

Noteworthy, for enzymes from fruiting bodies, the substrate specificity is shown only for natural substrates.

\section{Molecular mass}

According to the literature, there are three proteinases from the P.ostreatus fruit bodies with similar molecular weight in the region of 30-40 kDa. The molecular weight of the aspartic enzyme obtained from the culture fluid of P.ostreatus is $45 \mathrm{kDa}$. So, proteases from fruiting bodies and culture fluid are similar in molecular weight $[37,39,42]$.

\section{Prospects for the use of aspartate proteinases}

Cheesemaking. Several proteinases from animals, plants, and microbial sources possess the ability to coagulate milk under suitable conditions. It causes defects in flavor and texture as well as reduction in yield of cheese. However, a few microbial sources produce rennet substitutes, which meet the requirements of the stage of commercial production. Like chymosin, these substitutes are acid (aspartyl) proteinase similar in molecular and catalytic properties. The specificity of rennet substitutes from fungal sources such as
Mucormiehei, Mucorpusillus and Endothiaparasitica is quite different. The acid proteinases of M. miehei and M. pusillus, like chymosin, preferentially hydrolyze the same Phe105-Met106 bond of kappa-casein, whereas those of E. parasitica preferentially cleave the Ser104-Phe105 bond [43-45]. Although microbial rennet is relatively cheap, fungal proteases have attracted the attention of industrial enzymologists and biotechnologists. The gene for prochymosin has been cloned in Escherichia coli, Saccharomyces cerevisiae, Kluyveromyces marxianus var. lactis, Aspergillus Nidulans, Aspergillus Niger, and Trichoderma Reesei [43, 46]. The enzymatic properties of the recombinant enzymes are indistinguishable from those of calf chymosin. The recombinant chymosin has been assessed on numerous cheese varieties, always with very satisfactory results. Three recombinant chymosins are now marketed commercially. Microbial chymosins have taken market share from both calf rennet and fungal rennet and now represent $35 \%$ of total market.

The gene for Rhizomucor Miehei proteinase has been cloned and expressed in Aspergillus Oryzae. It is claimed that this new rennet (Mazyme GM) is free of other proteinases or peptidases activities that are present in fungal rennet and may reduce cheese yield. Cloning the gene for $R$. miehei proteinase has created the possibility for site-directed mutagenesis of the enzyme [43, 47].

There are data in the literature concerning the preparation of milk-clotting proteinases from the extract of the fruit bodies of $P$. ostreatus, which resembles those used in the dairy industry. The preparation of milk-clotting enzyme was obtained from the culture fluid, 
which has a more significant milk-clotting activity than the enzymes obtained from fruiting bodies. Isolation, purification and study of the properties of these enzymes are a necessary vector for modern biotechnology [41, 42].

\section{Fibrinolytic properties of fungal proteases}

It is known that fibrinolytic enzymes dissolve the blood clots, which are formed as a result of the conversion of fibrin through the proteolytic action of thrombin [59]. The formation of a fibrin clot and fibrinolysis is usually well balanced in biological systems. However, when fibrin cannot hydrolyze because of some disorder, thrombosis may occur. Myocardial infarction is the most common of these thromboses. Cardiovascular diseases, including acute myocardial infarction, are the leading causes of death worldwide [48].

Non-physiological reagents (enzymes from snake venom, bacterial enzymes, fungal enzymes, etc.) are used as tools for studying the molecular mechanisms of the hemostasis system, as well as for diagnosing the disorders of this system. The advantage of such reagents lies in their unique specificity, in the absence of their inhibitors in the human blood, as well as in their resistance to high ionic strength and the presence of calcium ions [49].

Powerful fibrinolytic enzymes from various sources have been discovered over the past decade. One of the promising sources for obtaining fibrinolytic enzymes is the enzymes from the common P.ostreatus. There are some reports about isolation and purification of fibrinolytic proteinases from fruiting bodies [ 37 , $38]$, as well as from the culture fluid of P.ostreatus [42]. Recently it has been shown that proteinase from the culture fluid of oyster mushroom ordinary selectively degrades the Aa chain of fibrinogen, cleaving first the polypeptide with a molecular mass of approximately $3 \mathrm{kDa}$, and then another portion with a molecular weight of $10-15 \mathrm{kDa}$. This is an attractive direction for the future investigations in this field.

Antiseptic.There are data on the antibacterial and antifungal activity of extracts and isolated compounds from P.ostreatus, which is believed to function as a defense mechanism of the fungus against other organisms. It was shown that P.ostreatus has antibacterial activity against gram-negative aerobic bacteria that cause such dangerous diseases as pneumonia, bacterial corneal ulcers. The studies have proven that [the] fruit body extract stops the growth of E. coli. Lovastatin contained in the P.ostreatusfruit bodies was proven to be effective in treating malaria. P.ostreatus also has an antiallergic effect in case of atypical bronchial asthma, allergic rhinitis, drug allergies [48].

The purified enzyme complex from $P$. ostreatus mycelium extract exhibits intense antimicrobial activity and can be successfully used to develop more powerful and effective antimicrobial agents. The authors suggest the use of this enzymatic preparation to inhibit the growth of Pseudomonas aeruginosa and Streptococcus pneumonia, which are wellknown infectious agents [48, 50, 51].

Thus, the study of the structure and properties of aspartic proteases of fungal origin is important not only for basic research in the field of enzymology, it also opens up new prospects for their targeted use in various fields of modern biotechnological production at food and pharmaceutical enterprises. 


\section{REFERENCES}

1. Germano S, Pandey A, Osaku CA. Characterization and stability of proteases from Penicilliumsp. produced by solid-state fermentation. Enzym Microb Technol. 2003; 32:246-51.

2. Rawlings ND, Barrett AJ. Evolutionary families of peptidases. Biochem J.1993;290 (Pt1):205-18.

3. Rao MB, Tanksale AM, Ghatge MS, Deshpande VV. Molecular and biotechnological aspects of microbial proteases. Microbiol Mol Biol. 1998; 62: 597-635.

4. Sumantha A, Larroche C, Pandey A. Microbiology and industrial biotechnology of food-grade proteases: a perspective. Food Technol Biotechnol. 2006; 44 (2): 211-20.

5. Palmieri $G$, Bianco $C$, Cennamo G, Giardina $P$, Marino G, Monti M, Sannia G. Purification, characterization, and functional role of a novel extracellular protease from Pleurotusostreatus. Appl Environ Microbiol. 2001; V. 67: 2754-59.

6. Faraco V, Palmieri G, Festa G, Monti M, Sannia G, Giardina $P$. A new subfamily of fungal subtilases: structural and functional analysis of a Pleurotus ostreatus member. Microbiology. 2005;151(Pt 2): 457-66.

7. Shin $H H$, Choi HS. Purification and characterization of cysteine protease from Pleurotusostreatus. Biosci Biotechnol Biochem. 1998; V. 62: 1416-18.

8. Denisova NP. Nature and biological role of basidial fungi proteinases. Mycol Phytopathol. 1984; 18: 116-21.

9. Terashita T, Inoue T, Nakaie Y, Yoshikawa K, Shishiyama $J$. Isolation and characterization of extra- and intra-cellular metal proteinases produced in the spawnrunning process of Hypsizygusmarmoreus. Mycoscience. 1997; 38: 243-45.

10. Morozova EN, Falina NN, Denisova NP, Barkova LV, Psurtseva NV, Samartsev MA, Shitova VA. Analysis of the component composition and substrate specificity of a fibrinolytic drug from the fungus Flammulinavelutipes. Biokhimia. 1982; 47: 1181-85.

11. Choi HS, Sa YS. Fibrinolytic and antithrombotic protease from Ganodermalucidum. Mycologia. 2000;92(3):545-52.
12. Terashita T, Oda K, Kono M, Murao S. Purification and some properties of metal proteinases from Lentinusedodes. Agric Biol Chem. 1985; 49(8):2293-300.

13. Dohmae N, Hayashi K, Miki K, Tsumuraya Y, Hashimo $Y$. Purification and characterization of intracellular proteinases in Pleurotusostreatus fruiting bodies. Biosci Biotechnol Biochem. 1995; 59:2074-80.

14. Choi HS, Shin HH. Purification and partial characterization of a fibrinolytic protease in Pleurotusostreatus. Mycologia. 1998; 90:674-79.

15. Kobayashi H, Kasamo K. Crystallization and preliminary X-ray diffraction studies of aspartic proteinase from Irpexlacteus. J Mol Biol. 1992; 226:1291-93.

16. Kobayashi H, Kusakabe I, Murakami K. Purification and characterization of a pepstatin-insensitive carboxyl proteinase from Polyporustulipiferae (Irpexlacteus). Agric Biol Chem 1985; 49(8):2393-7.

17. Palmieri G, Bianco $C$, Cennamo G, Giardina P, Marino G, Monti M, Sannia G. Purification, characterization, and functional role of a novel extracellular protease from Pleurotusostreatus. Appl Environ Microbiol. 2001; 67(6):2754-59.

18. Akhmedova ZR. Cellulolytic, xylanolitic and lignolytic enzymes of the fungus Pleurotusostreatus. Prikl Biochim Microbiol. 1994; 30:42-8.

19. Denisova NP. Proteolytic enzymes of basidial fungi, taxonomic and ecological aspects of their study. Thesis Doc Biol sci. 1991; 31.

20. Veerapandian B, Cooper JB, Sali A, Blundell TL, Rosati RL, Dominy BW, Damon DB, Hoover DJ. Direct obser-vation by X-ray analysis of the tetrahedral "intermediate" of aspartic proteinase. Protein Sci. 1992;1(3) 322-8.

21. Andreeva NS, James MN. Structure and function of aspartic proteinases. N.Y.: Plenum Press. 1992; 39-45.

22. Antonov VK, Ginodman LM, Rumsh LD, Kapitannikov YV, Barshevskaja TN, Yavashev LP, Gurova $A G$, Volkova LI. Studies on the mechanisms of action of proteolytic enzymes using heavy oxygen exchange. Eur J Biochem. 1981; 117:195-200.

23. Davies DR. The structure and function of the aspartic proteinases. Annu Rev Biophys Chem. 1990; 19:189-215. 
24. Andreeva NS, Rumsh LD. Analysis of crystal structures of aspartic proteinases: on the role of amino acid residues adjacent to the catalytic site of pepsin-like enzymes. Protein Science. 2001; 10(12): 2439-50.

25. Piana S, Carloni P. Impact of genetic variation on three dimensional structure and function of proteins. Proteins: Structure, Function, Genetic. 2000; 39:26-36.

26. Avtonomova AV, Krasnopol'skaia LM, Maksimov $V N$. [Optimization of nutrient medium for submerged cultivation of Ganoderma lucidum (Curt.: Fr.) P. Karst]. Mikrobiologiia. 2006;75(2):186-92. Russian.

27. Kalizs HM, Wood DA, Moore D. Production, regulation and release of extracellular proteinase activity in basidi-omycete fungi. Trans Br Mycol Soc. 1987; 88:221-227.

28. Dunaevsky YE, Matveeva AR, Belyakova GA, Belozersky $M A$. Degradation of protein substrates by xylotrophicba-sidiomycetes. Microbiology. 2006; 75:46-51.

29. Claverie-Martìn F, Vega-Hernàndez MC, Aspartic proteases used in cheese making. Industrial Enzyme. 2007: 207-19.

30. Van SSC, Warnock NI, Schmidt S. Aspartic acid protease from Botrytis cinerea removes haze-forming proteins during white winemaking. J Agricult Food Chem. 2013; 61, 40, 9705-11.

31. Jacob M, Jaros D, Rohm H. Recent advances in milk clotting enzymes. Int J Dairy Technol. 2011; 64 (1):14-33.

32. Rao MB, Tanksale AM, Ghatge MS, Deshpande VV. Molecular and biotechnological aspects of microbial pro-teases. Microbiol Mol Biol Rev. 1998; 62(3):597-63.

33. Theron $L W$, Divol B. Microbial aspartic proteases: current and potential applications in industry. Appl Microbiol Biotechnol. 2014; 98(21):8853-68.

34. Cutfield SM, Dodson EJ, Anderson BF. The crystal structure of a major secreted aspartic proteinase from Candida albicans in complexes with two inhibitors. Structure. 1995; 3(11):1261-71.

35. Kobayashi H, Kim H. Characterization of aspartic proteinase from basidiomycete, Laetiporus sulfureus. Food SciTechnol Res. 2003; 9:30-34.
36. Gershkovich AA, Kibirev VK. Khromogennye i fluorogennye peptidnye substraty proteoliticheskikh fermentov [Chromogenic and fluorogenic peptide substrates of proteolytic enzymes]. Bioorg Khim. 1988;14(11):1461-88. Russian.

37. D'jakonova $G V$. The study of some physico-chemical properties of milk-clotting enzymes of oyster mushroom. 03.01.04 VAK RF, Kazan state University, Rostov-on-don. 2010; 44.

38. Lebedeva G, Proskuryakov M. Purification and characterization of milkclotting enzymes from oyster mushroom (Pleurotusostreatus (Fr.) Kumm). Applied Biochemistry and Microbiology. 2009; 45(6):623-625.

39. Dmitrieva TA, Kolesnikov BA, Shamtsyan MM. Screening of producers of milk-converting enzymes among cultures of higher basidiomycetes. Nat tech Sci. 2009; 3(41):145-7.

40. Chemerys OV, Boyko MI. The milk coagulating activity of some basidial wood-destroying fungi. Donetsk readings. 2016; 229-32.

41. Sakovich VV, Grusha AM, Zhernossekov DD. Guidelines for obtaining a drug with milk-clotting activity from Pleurotusostreatus.Vet J Belarus. 2018; 63-67.

42. Sakovich VV, Stohniy YM, Zhernossekov DD, Rebriev AV, Korolova DS, MarunychRYu, Chernyshenko VO.Metalloprotease from the cultural liquid of Pleurotusosreatus. Biotechnologia Acta. 2019; 12(6):35-45.

43. Kudryavtseva OA, Dunaevsky YE, Kamzolkina V, Belozersky $M A$. Proteolytic enzymes of fungi: features of extracellular proteases of xylotrophicbasidiomycetes. Microbiology. 2008; 77:725-37.

44. Chemeris OV, Rashevsky VV, Boyko MI. Milk-curdling activity of some basidial wood-destroying fungi. Problems of ecology and nature protection of the technogenic region. 2016; 1(2):77-82.

45. Shpirnaya IA, Shlyapnikova SV, Tsvetkov VO, Ibragimov RI. Milk-clotting activity of basidial fungi enzymes. Reports of the Bashkir University. 2016; 1(1):63-67.

46. Shlyapnikova SV, Batyrova ER, Tsvetkov VO, Shpirnaya IA.The study of milk clotting activity of the enzymes of bracket-fungus. Proc Ufa Sci Ctr RussAcad Sci. 2017; 3(1):228-232. 
47. Shlyapnikova SV, Batyrova ER. Features of milk coagulation: rennet enzyme preparation and its analogues. BIOmics. 2017; 9(1):33-41.

48. Belova NV, Shamolina II. Some promising areas of biotechnology of basidiomycetes. Mycol Phytopathol. 2013; 47(2):73-82.

49. Sorokin SS. Tromboliticaskie and fibrinolytic properties of basidiomycetes. Tradit Innov. 2017; 270.

50. Efremenkova $O V$. Antibiotics for basidial fungi. $A d v$ Med Mycol. 2018; 18:240-5.

51. Tsivileva OM, Perfileva AI, Pavlova AG. Antibacterial potential of a biomaterial of fungal origin with a low content of biometals. Meth Comp Diagn Biol Med. 2018;153-6.

\section{Структурні та функціональні особливості аспарагінових протеаз базидіоміцетів}

\section{В. В. Сакович}

Величезне різноманіття грибних протеаз та специфіка ï дії привернули увагу при спробах використання їх фізіологічних та біотехнологічних властивостей. Ціферменти широко використовуються в біотехнології, головним чином у харчовій, шкіряній промисловості, у виробництві миючих засобів, в процесах екологічної біоремедіації та для отримання терапевтичних пептидів, що знаходять застосування в якості медичних препаратів. Цей огляд охоплює різні аспекти аспарагінових протеаз базидіоміцетів, включаючи джерела іх отримання, продукцію, структурні особливості, фізико-хімічні властивості та їх різноманітне застосування.

К л юч о в і с л о в а: протеолітичні ферменти, фізичні і хімічні властивості

\section{Структурные и функциональные особенности аспарагиновых протеаз базидиомицетов}

В. В. Сакович

Разнообразие протеиназ грибного происхождения и специфика их действия широко используются, благодаря их физиологическим и биотехнологическим свойствам. Данные ферменты широко используются в биотехнологии, главным образом в пищевой, кожевенной промышленности, в производстве моющих средств, в процессах экологической биоремедиации и для получения терапевтических пептидов, которые находят применение в качестве медицинских препаратов. Этот обзор охватывает различные аспекты аспартатных протеиназ базидиомицетов, включая источники их получения, продукцию, структурные особенности, физико-химические свойства и их разностороннее применение.

Кл юче в ы е с л о ва: протеолитические ферменты, физические и химические свойства

Received 30.01.2020 